\author{
Joanna Hernik \\ Zachodniopomorski Uniwersytet Technologiczny w Szczecinie \\ Wydział Ekonomiczny \\ e-mail: jhernik@zut.edu.pl
}

\title{
Society awareness, competition and cooperation with business as determinants of marketing management in non-governmental organizations
}

Codes JEL: M30, M39, O52

Keywords: competition, cooperation with business, marketing management, mass-media, society and politics.

Summary. In developed economies, commercial and non-profit spheres grew in parallel and both had enough time to go through various phases. In Poland, the economy (which was liberated only in 1990s) transformed rapidly to meet new challenges but the same cannot be said about non-governmental organizations (NGOs), which are also developing dynamically but the management seems to be more difficult. Therefore the aim of the article is to establish key factors of marketing management in case of such organizations and indicate their uniqueness in the case of non-profit activity. Theoretical part is supported by a self-study questionnaire, results of which show that marketing management depends on internal factors of course, like leaders' education and philosophy, but first of all on external ones. Thus in this article society's awareness about NGOs activity as well as competition on entry and on exit, and contractual and relational cooperation between business and NGOs are discussed as main external determinants of marketing management.

\section{Introduction}

„Management” may be defined as using and coordinating resources, such as capital, property and labor, in order to achieve goals (Sudoł, 2007, p. 23), and 
activities included into management are: planning, organizing, motivating, and controlling. One of the types of management is „marketing management”, which - according to a definition by Ph. Kotler - is a social and managerial process that helps certain individuals and groups obtain what they need by means of exchange which is satisfactory to both parties (Kotler, 1975, p. 8).

It should be noted that in Poland there are 100,000 NGOs; among them, there are associations $(73,000)$, voluntary fire brigades (over 15,000) and foundations $(11,000)$. Every year, the number of entities increases by approx. 3,000. They have approx. 10 million members and 1 million volunteers (Basic data..., p. 3,10$)$. Main domains of activity in Poland are: sport \& tourism; education \& upbringing; arts \& culture; health promotion; social services, and local development.

It has been stated that marketing management is a social and managerial process which involves an exchange of values between entities and the environment. One needs, therefore, to begin with a question: What are the needs of organizations and what are the needs of the environment in the exchange process? Entities need members and volunteers, as well as various material and financial resources. In return, they can offer job opportunities whereby employees can improve their knowledge and skills, as well as satisfy their higher needs, such as satisfaction, a sense of a fulfilled duty and sense of improving others' life. There are two types of factors which can influence the methods of managing an entity - external and internal. Internal factors surely are: resource type, competences of employees (especially the management) and market objectives that are being pursued. External factors include: market structure, competition, demand for particular goods, as well as general legal, political and economic circumstances. This article discusses the activities of NGOs (nongovernmental organizations) that should also implement marketing management. The aim of this paper is to specify determinants of implementation of marketing management, as they are different from determinants of commercial entities and outline nonprofit marketing uniqueness. In the business sphere, activities are conditioned by demand and supply. However, in the non-commercial sphere, the main need is to convince leaders that marketing is effective. Among external determinants one may list: beneficiaries' profile, community's awareness of an organization, presence of other entities (competition), ties with businesses, as well as social and political realities. This paper discusses these issues. The empirical part discussed in the text comes from own study of Polish NGO leaders, as well as on study involving individuals (research involved 566 organizations and 1560 individuals).

\section{Communities' awareness and perception of entities}

As mentioned before, while answering the question „How does the environment influence entity's marketing management?", we should focus on society's 
awareness of organizations and behaviors of various interest groups (incl. willingness of businesses to support NGOs). Society's awareness of entities depends mostly on the profile of individuals in question: younger versus older, educated versus uneducated, involved in social matters versus passive. The average Pole who is the target of entities' calls for help is - statistically - an almost 39-yearold catholic who lives in the city. Poles have heard about NGOs before - research of 1,560 respondents suggests that $86.9 \%$ of Poles are aware of existence of such entities, and almost $75 \%$ are able to name one specific entity. On the other hand, only $12 \%$ of Poles are members of any association/initiative. Interestingly, southeastern Poland is more aware of existence of charities (there is statistically significant difference between this region and other regions; (chi-squared $\left.\mathrm{x}^{2}=13.1122 ; \mathrm{df}=5 ; \mathrm{p}=0.02236\right)$.

Moreover, regions in Poland differ in terms of determinants that condition the support for organizations; north-western Poland believes that an entity should be present in mass media to receive support. The highest level of disagreement with this belief has been noted in south-western Poland. South-western Poland values the sense of ,doing something good" more than Poles in other regions. The study also suggests that willingness to help others coincides with higher education, older age and higher income. Average Pole's opinion on NGOs is based on their previous encounters (experiences), opinions of their family and friends, as well as declarations voiced by entities themselves. For this reason, organizations should not stir unrealistic hopes if they are not able to fulfill the promises. They should, however, make some promises, as this conditions entity's success on the market. It results from the fact that recipients of entity's activity (divided into beneficiaries and other stakeholders) expect their needs to be met. For potential volunteers and donors, these needs are often intangible, such as satisfaction, a sense of a fulfilled duty, improving others' life, as well as a chance to fulfill one's social or professional aspirations - which may all be described as ,the sum of expected benefits". However, there is a problem with entities' visibility: although most of respondents have heard about NGOs, only half of them see these organizations in their communities (Fig. 1). In such circumstances, potential stakeholders will not be willing to devote their time and knowledge to NGOs and if they do support them, they tend to send sponsored text messages or use the $1 \%$ tax deduction instead. Responses visible in Fig. 1 suggest that half of Poles do not know whether NGOs operate in their milieu, which in turn suggests that information about NGOs are supplied by mass media, not personal contacts. The biggest proportion of respondents who were uncertain of NGOs' existence or believed that there were none active in their environment, was noted in the countryside; second biggest proportion was noted in large cities (Tab. 1; there was no statistically significant correlation between awareness of NGOs and place of res- 
idence - chi-squared $\mathrm{x}^{2}=14.428 ; \mathrm{df}=6 ; \mathrm{p}=0.252$ ). It is worth noting that countryside respondents' answers are largely justified, as majority of Polish NGOs operate in the cites (Herbst, Przewłocka, Adamiak, 2013). Thus, city dwellers are more aware of these entities than countrymen. What is more, $87 \%$ of Poles do not engage in any type of NGO, therefore awareness of their existence and knowledge about their activities may be very limited.

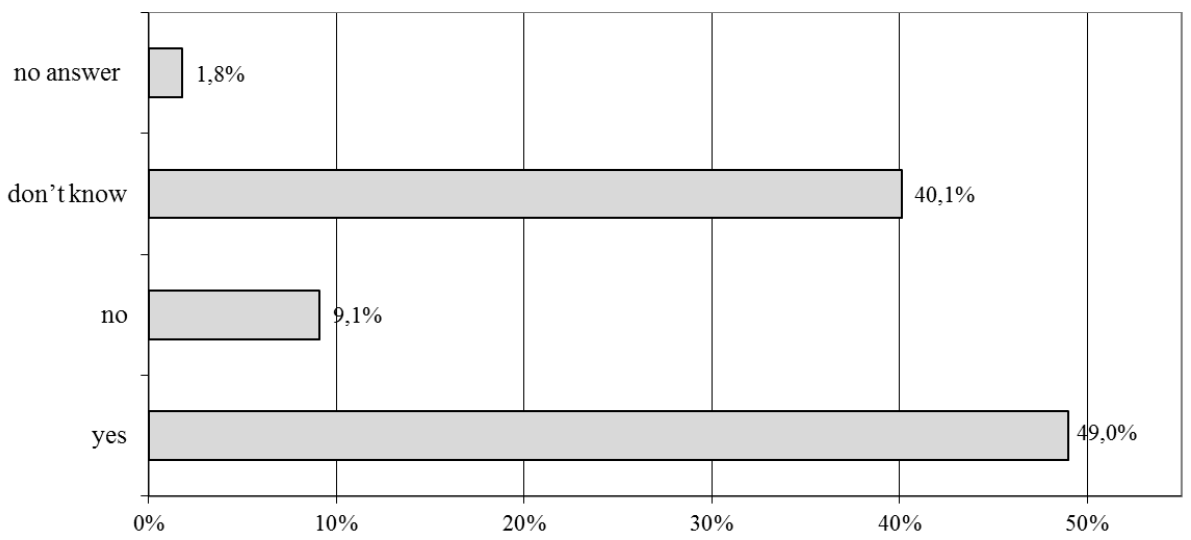

Figure 1 . Is there a charity organization active in your community? $(\mathrm{N}=1560)$

Source: author's own study.

Table 1

Awareness of NGOs' existence based on place of residence of respondents $(n=1323)$

\begin{tabular}{|l|c|c|c|c|c|c|c|c|}
\hline \multirow{2}{*}{$\begin{array}{l}\text { Is there an organiza- } \\
\text { tion active in your } \\
\text { community? }\end{array}$} & \multicolumn{2}{|c|}{ village } & \multicolumn{7}{|c|}{ town up to 50,000 } & \multicolumn{2}{|c|}{ town over 50,000 } & \multicolumn{2}{c|}{$\begin{array}{l}\text { city over } \\
200,000\end{array}$} \\
\cline { 2 - 10 } & $\mathrm{Qt}$ & $\%$ & $\mathrm{Qt}$ & $\%$ & $\mathrm{Qt}$ & $\%$ & $\mathrm{Qt}$ & $\%$ \\
\hline Don't know & 123 & 44.6 & 120 & 36.8 & 106 & 38.3 & 191 & 43.1 \\
\hline Yes & 117 & 42.4 & 174 & 53.4 & 149 & 53.8 & 220 & 49.5 \\
\hline No & 36 & 13.0 & 32 & 9.8 & 22 & 7.9 & 33 & 7.4 \\
\hline Total & 276 & 100.0 & 326 & 100.0 & 277 & 100.0 & 444 & 100.0 \\
\hline
\end{tabular}

Source: author's own study.

Since so many Poles do not see NGOs in their community, it may be assumed that they have never had direct contact with any representative of local entities. These respondents also have no direct knowledge about the organization, which reduces their willingness to participate and support them, and in turn hinders NGOs' operations. Some of NGOs are well-known from the mass media. $74.8 \%$ of respondents were able to name an NGO, which is a significant result in terms of $1 \%$ tax deduction awareness campaigns. As mentioned before, these 
NGOs are often supported with $1 \%$ tax deduction, as well as sponsored text messages or donations (food, clothes etc.).

The circumstances described above illustrate the realities in which NGOs must operate. Their marketing success is conditioned by society's attitude and awareness, as well as citizens' willingness to get engaged into social matters. Negative opinions about organizations lead to ignoring or criticizing them by general public, which causes a difficult situation which may be improved by information campaigns provided by institutions (both private and public) that promote the third sector. When the general attitude towards NGOs is positive, their marketing activities will be met with positive responses easier and quicker.

The study revealed that some respondents do not engage in NGOs' activities at all, therefore it would be advisable to establish which factors might condition their involvement. During author's own study, Poles were asked about their motives for supporting NGOs. They underlined that they needed to know precisely what the funds were spent on; next, they highlighted the sense of „doing something good"; they also pointed out that they wanted to have access to various information about the entity ( $\mathrm{p}<0.05$; Spearman's rank correlation coefficient between 0.01 and 0.08 ). It was observed that financial support is usually offered by respondents aged 31-40, while time and labor is offered by those below 20 . The study also revealed that the older the respondents, the more importance they give to NGOs' presence in the media, as well personal relations with organization members or beneficiaries - which is noteworthy, given aging of the society.

How do Poles assess NGOs' activity and credibility? The average assessment was 3.44 (on a 1 to 5 scale). Despite this quite neutral result, as many as $97.2 \%$ of respondents believed that one should help others. This suggests that respondents' attitudes towards NGOs is quite unclear, which may stem from their personal situation, experiences or lack of deep knowledge about NGOs. Acceptance of NGOs activity depends mostly on personal experiences and gender, and is subjective, which means it is based on satisfaction from previous contacts or trust for organizations (Iwankiewicz-Rak, 2006, p. 35). Trust - in turn - depends on entity's behaviors, as well as on general realities of the society. Therefore, we may state that marketing management depends on society's awareness: the better awareness of NGOs, the more effective their marketing activities will be.

\section{Competition in the NGO sector}

The market analysis of NGOs suggests that entities behave differently when there are other organization providing similar service on the market, compared to when they are „monopolists”. Therefore, external determinants of marketing orientation include existence of competition and demand for a given type of services. 
"Competition" relates to a market situation wherein entities compete with each other in order to achieve similar aims. Competitiveness is usually described as ability to effectively compete (to be better) within particular structures, at a particular time. The term is usually related to enterprises, where it means ability to stay on the market (Smith, Stebbins, 2006, p. 17-18; Drucker, 1990, p. 76). Can NGOs' situation be considered in a similar manner? And if so, what do NGOs compete for? It seems that the answer should encompass two spheres: competition on entry and on exit.

Competition on entry focuses on various resources, such as raw materials and semi-finished goods, capital, land, property, information, know-how, as well as knowledge of people and their work. These elements are subject to competition if they are not abundant in terms of quantity and quality. NGOs compete with each other to obtain members, volunteers, information and donors' support. Both people and funds are necessary for an organization to be able to operate. Therefore, if these resources are limited, when one entity gains them, it hinders or even prevents other entities from operating. As a result, even if one entity focuses on health promotion, and another on culture, both compete for the same resources, which makes them competitors.

On the other hand, competition on exit relates to whether or not the recipients will accept NGO's offer. Notably, theories state that competition appears only on the buyer's market, i.e. when demand is lower than supply (Smith, Stebbins, 2006, p. 22-25). Because intensity and nature of competition conditions NGOs' behaviors (incl. marketing activities), we may state that NGOs compete on exit for resources, which is shown in Fig. 2.

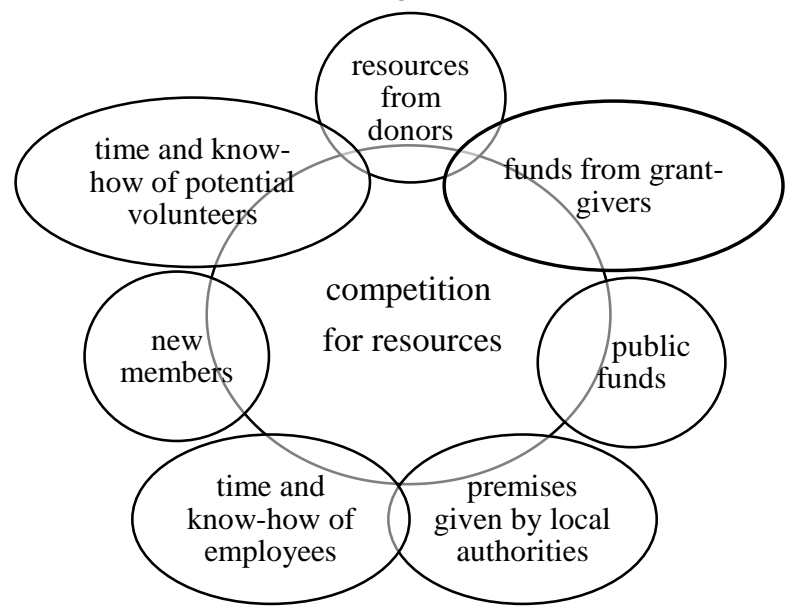

Figure 2. Competition among NGOs for resources

Source: author's own study. 
So, NGOs compete on exit for resources, especially for donors and volunteers, while there is no competition for beneficiaries (to accept NGOs' offer). Therefore, entities need to shape their marketing management in order to obtain resource necessary to operate on the market. Here, the term ,resources" may be understood as anything that helps to run and develop the organization.

Organizations may obtain various resources from individuals, businesses and public administration. For example, self-government bodies offer funds for NGOs, as well as premises to carry out their activities. Resources offered by business are not only financial, but also material, such as office equipment or furniture, which may be donated to NGOs. Nowadays, commercial entities engage more and more frequently in NGOs' activities, creating a social responsibility business concept. As mentioned, they donate material resources as well as time and know-how of their employees. NGOs may also attract society's attention, as society is not only a source of financial help, but also new members, volunteers and donors. All these aims require suitable marketing activities, based on a developed strategy.

There are practically no barriers to accept NGOs' offer - both of sports \& recreation-minded NGOs, as well as education \& upbringing or health-oriented ones. Given their laudable aims, these NGOs may count on the help from their supporters. Marketing activities may be, therefore, less intense. We might stop with this simple statement, if it wasn't for the fact that every year the number of NGO increases by a couple of thousands and there are areas where they are very active. For example, the biggest number of sports-oriented NGOs (per 10,000 citizens) operate in Zachodniopomorskie, Lubuskie, Lubelskie, Podkarpackie and Małopolskie voivodeships. Social services and employment boosting NGOs are most numerous in the north of Poland: in Zachodniopomorskie, Pomorskie, Warmińsko-mazurskie and Świętokrzyskie voivodeships, therefore it is more difficult to obtain funds in those regions. Additionally, there are many NGOs that focus on areas other than health or the disadvantaged; their competitors' activities will have even greater impact. Their marketing strategy should reflect that.

Competition on exit also presents many challenges. Organizations operate in many areas and on various scales, which means that competition in particular spheres and geographical areas is different. In every region, relation between demand and supply is varied, but it seems that demand is significantly higher than supply of services, especially in the area of social services for the ill and socially excluded. Their needs are much bigger that what NGOs and the market can offer. Depending on an area of entity's operation, methods of gaining resources and people are different. Marketing management must take into account these factors as well.

When a new organization appears (e.g. corporate foundations), they often strive for market share. However, ,share" is not meant as meeting the needs of as 
many beneficiaries as possible, but attracting potential donors and volunteers, and convincing them to engage. When a new organization became visible, others may organize intense information campaigns in response (which would create a barrier on entry), but due to the fact that few organizations are financially able to do that, new entities can enter the market quite freely. NGOs that are already present on the market may be better-known and experienced, but if a new entity had exclusivity in terms of generating/providing a service (technology, patents) or better funding than others (foundations), it may be able to promote itself actively and quickly become an established NGO.

Another factor that influences NGOs' situation, are public grants (national or EU funds); here, experienced entities that are well-known by public institutions and grant-givers will find themselves in a more advantageous position than new NGOs. Moreover, entities that carry out self-government's objectives are preferred (instead of NGOs with other aims). Therefore, public funding may offer advantage to some NGOs. As a result, marketing management needs to reflect focus on public funds (for NGOs completing self-government bodies' objectives) versus other sources of funds. We may state that a large number of NGOs and limited resources result in entities treating each other as competitors. This should force NGOs to change in terms of costs, offer and communication with donors and recipients - in short, in terms of marketing activities.

\section{Influence of contacts with businesses on management of NGOs}

In developed economies, business and non-profit spheres grew in parallel and both had enough time to go through various phases. In Poland, the economy (which was liberated only in 1990s) transformed rapidly to meet new challenges and had insufficient time to develop partner relations with other participant of this significant transformation. Although in the last 20 years NGO sector has developed dynamically, it was not followed by increased ties with businesses - only $32 \%$ of NGOs receive support from businesses (author's own study). Such low result may stem from the fact that NGOs are not able to present their offer to businesses well, while companies are not aware of benefits brought by such cooperation. It clearly indicates a need for marketing activities.

Willingness of businesses to support non-profit entities correlates with business leader mentality, as well as beneficial fiscal and legal regulations. Nowadays, NGOs in Poland may receive resources such as donations, gifts, grants, sponsored text messages, prize draws, loans and sponsoring. On the other hand, entrepreneurs - as natural persons - may support NGOs by donating $1 \%$ tax deduction (possible since 2003) towards public benefit organizations and offering other forms of donations. Currently, there are approx. 8,000 of public benefit organizations in Poland (7\% of total organizations). Entities may receive support 
from entrepreneurs: donations towards organizations reduce the tax base or increase costs, which is regulated by Art. 18 of the Corporate Income Tax Act (1992). Reduction of tax base depends on the form of taxation (the possibilities are: progressive tax with 18 and $32 \%$ thresholds; fixed tax of 19\%; flat-rate tax on registered income without deductible costs; tax deduction card). If an entrepreneur chooses general accounting principles or flat-rate tax on registered income without deductible costs and supports an organization, the donation will reduce the tax base in their annual income statement. According to regulations, the total of donation may not exceed $10 \%$ of income in a given tax period. It should also be noted that not all donations are treated in the same way. An entrepreneur may reduce their tax base if they support a public benefit organization, religious organization or donates blood. The following organizations are excluded from business support: created by political parties, trade unions and employers' associations. Some donations may be categorized as tax deductible expenses. These are mostly costs of purchasing or generating food products which are used for charity activities. Regulations do not determine an upper limit of such costs, but they may be taken into account only once, which means that cannot reduce the tax base.

Presented solutions do not allow supporting all organizations - only those described as public benefit organizations, religious organizations and blood donations, which in reality encompasses majority of organizations operating in Poland. Formally, entrepreneurs have numerous possibilities to run responsible businesses, but nowadays over $66 \%$ of organization do not cooperate with businesses at all (Fig. 3).

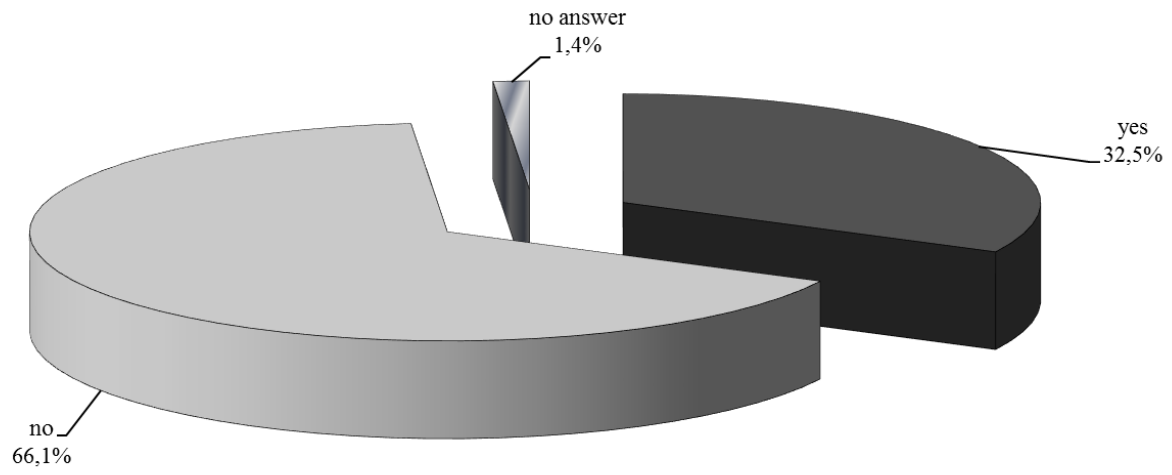

Figure 3. Do organizations cooperate with businesses? $(\mathrm{N}=566)$

Source: author's own study.

Problems with ties between NGOs and business have been confirmed by other authors, such as Herbst et all, who observed gradual decrease of ties, instead 
of closer cooperation (Herbst et all 2013). Entrepreneurs may support organizations without benefiting from tax reliefs, if that is their approach. Cooperation of NGOs and businesses may be contractual (for specific objective and time) or relational (wherein cooperation becomes part of strategies of both parties). In both cases cause-related marketing (CRM) may be used, i.e. cooperation based on joint activity of commercial and non-profit entities, aimed at laudable aim (McLeish, 1995, p. 192-207). CRM is often used in promotional campaigns, with funds donated towards organization are based on purchases made by the clients of the commercial entity (Tsai, 2009, p. 649-665). Irrespectively of the approach, such cooperation may lead to benefits for both parties.

There are two reasons for businesses to engage: belief in the cause (altruistic motivation) and belief that the cooperation will be profitable for the company (material motivation). Analysis of consumer behavior prove that if a promoted event/organization upholds the same values as the involved company, the audience respond to such cooperation very positively. Naturally, some companies use the cooperation with non-profit organization as a way to promote their products and image, which does not, in fact, reduce benefits for the organization itself and its beneficiaries (Meijer, de Bakker, Smit, Schuyt, 2006, p. 13-28).

Organizations benefit in terms of increased funds, material donations, higher involvement of volunteers and new members. Not all effects of CRM are visible immediately. Some of them (additional) appear in the future: brand recognition, stakeholders' interest, increased involvement of employees and members of the organization (Drucker, 1990, p. 415). It should be noted that cooperation with businesses increases professionalism of NGOs, as the entities need to reconsider their offer, plan the scope of cooperation and inform stakeholders about their intentions. NGOs' contacts with businesses may therefore change their approach to the management strategy, promoting plans of cooperation with businesses, tailoring offer to individual needs or developing communication with the general public. It means that contacts with businesses may positively change organization resources and the way it is managed. Apart from businesses, NGOs may cooperate with advertising agencies, media, and research companies whose know-how and time may be used to support selected activities. Some of these entities may help NGOs without promoting this fact - this is called philanthropy. Other will emphasize their partnership to promote company image. Both approaches may result in new resources for the NGOs, therefore they should be welcomed.

Businesses that decide to cooperate with NGOs expect them to present plans, organize their activities, report aim completion; as such, business-NGO cooperation may lead to significant changes within NGOs. However, it is believed that sometimes NGOs get so "professionalized” that they become similar to commercial entities, and their activity may be called ,comparity” (company \& 
charity) (Williams, 1999, p. 135-151). It is hard to determine whether it is a positive or negative trend. On the other hand, majority of NGOs must prove their effectiveness only to their members - this is not objective and does not promote true effectiveness, while NGO-business contacts force NGOs to reconsider and verify rationality of their activities. Given limited resources, it seems to be a positive trend.

Businesses often prefer to establish their own foundations instead of getting involved directly in NGOs and public organizations' activities. This may stem from their willingness to control the funds and monitor effects. When a company does get involved into supporting an organization, it prioritizes: media coverage, nature of its support and endorsement of respected individuals. Therefore, organizations must display certain level of professionalism when they cooperate with the media and present their objectives. This translates into a well thought-out marketing strategy.

\section{Social and political circumstances}

In Western Europe and post-socialist countries an increased strength of private non-profit organizations has been observed. As they complement public institutions, they are able to meet the needs and provide services not offered by government (or self-government bodies). It seems that the trend of completing public tasks by means of NGOs is here to stay. Legal regulations confirm this trend, as they command creation of cooperation programs for self-government bodies and local NGOs. Every year in Poland, local self-government bodies develop guidelines of cooperation with the third sector, based on the Act on Public Benefit Organizations and Volunteer Work. For example, municipal commune of Szczecin declared these areas as priorities in 2014:

- helping retirement-aged citizens,

- social services, incl. families and the disadvantaged, providing equal opportunities for these families and individuals,

- culture, art, protecting national heritage and culture,

- promoting and popularizing physical culture,

- helping the disabled,

- prevention of addictions and social pathologies,

- helping NGOs (Szczecin Municipal Program...).

To complete these priorities, competitions were called for organizations active in the following areas: helping the elderly, families and the disadvantaged as well as providing equal opportunities for them, providing shelter for the homeless, providing palliative care, financing integration and activation of the disabled, financing recreation for children and adolescents, preparing and organizing events, ventures and activities in the area of culture. 
Setting priority fields is a message for many organizations that they may obtain funding in those areas. Therefore, NGOs focused on social services, sports or addictions do not need to engage in donor-seeking and communicating with market. This, naturally, translates into different scope of marketing strategy and activities.

In terms of marketing management, cooperation initiatives advertised by self-government bodies will attract attention of NGOs and motivate them to obtain funds offered in competitions. Thus, marketing objectives of NGOs will be convergent with self-government bodies' aims. For example, municipal and commune budgets give priority to sports and social services. We may, therefore, assume that NGOs working in these areas will want to actively adjust their offer to the needs of self-government bodies. What is more, they often obtain only public funding, as it guarantees certain constant level of activity. Actually, NGOs do not need to fight among themselves for society's supports and sponsors, because local budgets assign considerable funds to selected areas. Publishing priority areas serves also as a clue as to which organizations might have problems with obtaining funds. Naturally, these will be NGOs working in the areas of local development, lifesaving, animal protection and science, as well as various hobbies, since these areas are not included into self-government bodies' priority lists. This means that marketing management will be connected to political and law regulations.

\section{Conclusions}

Implementation and scope of marketing management in case of NGOs activity depends on several external factors, i.e. society`s knowledge of organizations, competition, sphere of activity of an organization, legislation and political decisions. Of course this topic could be analyzed deeper and for example tradition of non-profit organizations functioning could be taken into account, or style of life and morality of people, however determinants discussed in this article seem to be crucial.

Marketing strategy and actions depend on society`s knowledge of organizations for sure - it turns that people know organizations that are present in mass media, and often are not aware that there are local NGOs doing a lot of for local communities. These organizations have to change behavior and start to meet people. And should be transparent, because discussed research shows that people expect detailed information about organization`s activity, especially in terms of using money.

Very interesting conclusion is that NGOs do not compete „on exit” (do not fight for customers), although competition, understood as doings in order to achieve similar aims, exists. In case of NGOs activity competition takes place „on entry” - organizations struggle for the same resources, because all of them need money and other material support, volunteers and their time and knowledge, 
etc. This specifics changes marketing strategy and all actions taken by an organization.

Moreover, sphere of activity is also important - the more important social problem they deal with, the easier is to get financial support, especially from local governments, and volunteers. And finally, legislation influences organizations behavior as well - these organizations that are allowed to collect $1 \%$ tax deductions and donations from business are focused on $1 \%$ campaigns and have to use mass communication to gain its milieu attention. The rest is more focused on local media and personal contacts, especially when they try to adapt to local governments programs.

In conclusion it can be mentioned also that in the future boundaries between public, private and self-government sectors will vanish, as NGOs have considerable funds at their disposal and they provide social services; companies create CRM programs or establish foundations active in the non-profit sphere (McLeish 1995, p. 26-27; Andreasen, Kotler, 2007, p. 35-40). Thus, quasi-public entities emerge; they do not, however, have rights or authority of self-governing bodies, which means that the status of such organizations is unclear. Quasi-social organizations also appear, whose function is twofold: complete laudable aims and promote their founding companies. All these factors change marketing management of NGOs, opening new possibilities.

\section{Bibliography}

Andreasen, A.R., Kotler, Ph. (2007). Strategic marketing for non-profit organizations. New Jersey: Prentice Hall.

Basic data of associations, foundations and social entities acting in 2010 [Podstawowe dane o stowarzyszeniach, fundacjach i społecznych podmiotach wyznaniowych działających w 2010]. (2010). Warszawa: Departament Badań Społecznych GUS.

Corporate Income Tax Act (1992) [Ustawa z 15 lutego 1992 r. o podatku dochodowym od osób prawnych, nr 21, poz. 86].

Drucker, P.F. (1990). Managing the non-profit organization. Oxford: Butterworth Heinemann Publ.

Herbst, J., Przewłocka, J., Adamiak, P. (2013). Basic facts of nongovernmental organizations. Report for 2012 [Podstawowe fakty o organizacjach pozarządowych. Raport z badania w 2012], Warszawa: Stowarzyszenie Klon/Jawor.

Iwankiewicz-Rak, B. (2006). Marketing społeczny w kształtowaniu wizerunku organizacji pozarządowych. Zeszyty Naukowe Uniwersytetu Szczecińskiego, 438, Ekonomiczne Problemy Ustug, 5, 28-31.

Kotler, Ph. (1975). Marketing for non-profit organization. New Jersey, Englewood Cliffs: PrenticeHall Inc.

McLeish, B.J. (1995). Successful marketing strategies for non-profit organizations. New York/Toronto: John Wiley \& Sons Publ.

Meijer, M.M., de Bakker, F., Smit, J.H., Schuyt, T. (2006). Corporate giving in the Netherlands 1995-2003: Exploring the amounts involved and the motivations for donating. Journal of Non-profit and Voluntary Sector Marketing, 11, 13-28. 
Smith D.H., Stebbins R.A. (2006). M.A. Dover, A dictionary of non-profits terms and concepts. Bloomington: Indiana University Press.

Sudoł, S. (2007). Nauki o zarządzaniu. Węzłowe problemy i kontrowersje. Toruń: Wydawnictwo Dom Organizatora.

Szczecin Municipal Program of Cooperation with NGOs for 2014 [Program współpracy Gminy Miasto Szczecin z organizacjami pozarządowymi oraz innymi podmiotami prowadzącymi działalność pożytku publicznego]. Retrieved from: http://bip.um.szczecin.pl.

Tsai, P.S. (2009). Modeling strategic management for cause-related marketing. Marketing Intelligence \& Planning, 27, 5, 649-665.

Williams, I. (1999). The development of purpose and strategy within British charitable organisations: Historical impressions. International Journal of Non-profit and Voluntary Sector Marketing, 4 (2), 135-151.

\section{Świadomość społeczeństwa, konkurencja i współpraca z biznesem jako determinanty zarządzania marketingowego $\mathrm{w}$ organizacjach pozarządowych}

Słowa kluczowe: konkurencja, współpraca z biznesem, zarządzanie marketingowe, mass media, społeczeństwo, polityka

Streszczenie: W krajach rozwiniętych sfery komercyjna i non profit rozwijały się równolegle i obie miały czas, aby przejść różne fazy rozwoju. W Polsce natomiast gospodarka (uwolniona na początku lat 90.) przeobrażała się gwałtownie, aby sprostać nowym wyzwaniom, czego z kolei nie można powiedzieć o organizacjach pozarządowych (NGOs), które także zaczęły się gwałtownie rozwijać, jednak mają większe problemy związane z zarządzaniem. Celem niniejszego artykułu jest ustalenie kluczowych czynników zarządzania marketingowego w przypadku takich organizacji oraz wskazanie ich wyjątkowości w przypadku działalności niekomercyjnej. Teoretyczną część artykułu wsparto własnym badaniem ankietowym, wyniki którego wykazują, że zarządzanie marketingowe zależy od czynników wewnętrznych, jak np. wykształcenie liderów i filozofia ich działania, ale głównie od czynników zewnętrznych. Dlatego w artykule świadomość społeczna na temat organizacji, konkurencja na wejściu i na wyjściu sektora non profit, a także kontraktowa i relacyjna współpraca między biznesem a NGOs przedstawiono jako główne determinanty zarządzania marketingowego.

Tłumaczenie: Joanna Hernik

\section{Cytowanie}

Hernik, J. (2016). Society awareness, competition and cooperation with business as determinants of marketing management in non-governmental organizations. Marketing i Zarzadzanie, 4 (45), 59-72. 